\title{
Study of the Application of the RCA and Six Sigma Method for Quality of the Kalimas River in Surabaya (Prestasi Park-Petekan Bridge Segment)
}

\author{
Ino Tri Wulansari ${ }^{1}$ and Nieke Karnaningroem ${ }^{1}$
}

\begin{abstract}
Kalimas River is a water body that passes through the city of Surabaya. The study was conducted on the Kalimas River (Segment of the Bridge Achievement Bridge) with a length of approximately $6 \mathrm{~km}$. Based on the results of the water quality test of the Kalimas River (Prestasi Park-Petekan Bridge Segment) in 2016, it was found that there were several parameters that did not meet the class II water quality standards, namely $\mathrm{BOD}, \mathrm{COD}$, DO, TSS, and Phosphate. According to the Surabaya City Regulation2014-2034, the Kalimas River will be used as atourist spot and river transportation service center, so the river water must meet the quality standards for water recreation areas, which is Class II water quality. Due to these problems, the research on controlling water quality is very important. This study uses the Six Sigma method with DMAIC concept. Six Sigma is a continuous improvement effort to determine variations in the process, in order to improve the capability of that process in producing products and minimizing defects. As a characteristic of Six Sigma, DMAIC consists of five stages, which are define-measureanalyze-improve-control. Some parameters that will be used are $B O D, C O D, D O, T S S, p H$, nitrogen, phosphateand total coliform. The first stage is "define",in which the water quality of the Kalimas River will be measured in the form of $B O D, C O D, D O$, TSS, pH, Nitrogen and Phosphate. Then the "measure" stage will be calculated as Deffect per Million Opportunities (DPMO) and sigma levels. In the "analyze" stage, the Root Cause Analysis (RCA) method is used to determine the root of the problem. "Improve" stage will determine potential solutions or action plans that can be applied. Then the "control" stage is conducted by making a plan to control the implementation of the action plan. The results of analysis at the six points show that there are several parameters that do not meet the Class II water quality standards, namely DO, BOD, COD, TSS, phosphate and total coliform. After calculating the Deffect per Million Opportunities in the "measure"stage, the value of the sigma level is 2.75. In the "analyze"stage, RCA method was used to find the root cause of the Kalimas River (Prestasi Park-Petekan Bridge Segment), and found the root cause was the inclusion of wastewater into rivers and river management systems.
\end{abstract}

Keywords- Water quality, Six Sigma, Kalimas River, Root Cause Analysis (RCA).

\section{INTRODUCTION}

Basically the function of water for people and other living things is very important, so that the presence of water must

${ }^{1}$ Ino Tri Wulansari and Nieke Karnaningroem are with Department of Environmental Engineering, Institut Teknologi Sepuluh Nopember, Surabaya, 60111, Indonesia. E-mail: Innotri.it@gmail.com; n.karnaningroem@gmail.com. be maintained in both quaantit and quality. The river is one source of raw water to meet the needs of the society[1]. According to Kementerian Pekerjaan Umum Bidang Pengairan JawaTimur (2011) the Kalimas river is one of the water bodies found in the cit of Surabaya. The existence of the Kalimas River which stretches in the middle of the cit of Surabaya and passes through densely populated areas causes the potential for pollution in the Kalimas river to be very high. Potential pollution of the Kalimas river in Surabaya is domestic waste sourced from residential areas, small industries around the river which directly dispose of liquid waste into the river. According to Peraturan Daerah Kota Surabaya Nomor 12 Tahun 2014 tentang Rencana Tata Ruang Wilayah Kota Surabaya Tahun 2014-2034 stated that Kalimas river will be used as a river tourist spot and center for river transportation service, so that based on these, the quality of the Kalimas river should meet the class II water quality standards.

In a study conducted by [2] which tested the quality of the Kalimas River (Prestasi Park-Petekan Bridge Segment), the results showed that there were several parameters that did not meet the class II water quality standards, namely BOD, COD, DO, TSS, and Phosphate. So we need a study that can provide a solution to improve the quality of the Kalimas river according to its designation, class II. The method used is the six sigma method.The Six Sigma method has many basic values such as the principles of process improvement, statistical methods, system management, continuous improvement and financial related improvements. There are five stages of DMAIC as a characteristic of Six Sigma, among others, define-measure-analyze-improve-control [3] it is expected that the six-sigma method can be a recommendation to control the quality of the Kalimas River in Surabaya.

\section{LITERATURE REVIEW}

\section{A. River Water Quality}

In an effort to control environmental pollution, especially pollution of river water in accordance with Peratutanpemerintah No. 82 of 2001 concerning water quality management and water pollution control in the third part (classification and water quality criteria), Article 8 states that the water quality classification is set into 4 classes 
a. First class, the water for which the designation can be used for drinking water raw water, and / or other designation which requires water quality that is the same as the utility.

b. Second class, the water for which the designation can be used for infrastructure / recreational facilities for water, cultivation of fresh water, livestock, water for irrigating plantations, and / or other designation which requires water quality that is the same as that use

c. Third class, the water for which the designation can be used for the cultivation of freshwater fish, livestock, water for irrigating crops, and / or other designations that require water that is the same as that use.

d. Fourth class, the water which can be use to irrigated the plant and for other function which requires the same quality as that.

\section{B. Six Sigma Method}

Six Sigma is a continuous improvement effort to reduce the variation of the process, in order to improve the capability of the process, to produce a product (goods and service) without problem to provide value to customers. The six sigma method has many basic values of assessment such as the principles of process improvements[3].

According to [4] six sigma can be interpreted simply as a process that has a probability of disability $0,00034 \%$ or 3,4 units of disability in one million units produced. The six sigma method is using DMAIC method. DMAIC method consists of five phases which is define-measure-analyseimprove-control[5].

\section{METHODOLOGY}

\section{A. Research Area}

In this research, the place of the research is Kalimas river, Surabaya. The river is from the segment of Prestasi Park until Petekan Bridge, that has a length of $4,0035 \mathrm{~km}$. The existence of the Kalimas river which runs in the middle of the city of Surabaya through densely populated areas causes a high potential for pollution in Kalimas river.

\section{B. Segments Determination}

This research will be conducted on Kalimas river with a length of approximately $6 \mathrm{~km}$ from upstream (bridge at YosSudarso street) to downstream (Petekan bridge). This river divide into five segments. This segments based on input from creek, sampling places, curves, change in the rivers dimension, and the output of river into creek. The segments can be see in Figure 1 This five segments are as follows :

\section{1) Segment 1 (Point A - Point 1)}

Point A is located on the bridge at Yos Sudarso Street and point 1 is located on the bridge at Genteng Kali Street. The length of this segment is $1,2 \mathrm{~km}$. This segment divided based on the input from creek into Kalimas river and the output from Kalimas river into creek.

\section{2) Segment 2 (Point 1 - Point 2)}

Point 1 is located on the bridge at Genteng kali street and point 2 is located on the Peneleh Bridge at the Achmad Jaiz street. The length of this segment is $0,89 \mathrm{~km}$. This segment divided based on a curve.

\section{3) Segment 3 (Point 2 - Point 3)}

Ponit 2 is located on the Peneleh Bridge at Achmad Jaiz street and point 3 is located on the bridge at Kebon Rojo street and point. The length of this segment is $1,58 \mathrm{~km}$. This segment ids divided based on a curve and the change in the dimensions of Kalimas River.

\section{4) Segment 4 (Point 3 - Point 4)}

Point 3 is located on the bridge at Kebon Rojo street and point 4 is located on the Merah bridge. The length of this segmen is $0,75 \mathrm{~km}$. This segment divided based on the change of the dimensions of Kalimas river

5) Segment 5 (Point 4 - Point B)

Point 4 is located on the Merah bridge and point $B$ is located on the Petekena bridge. The lenth of this segment is 1,64. This segment divided based on the change of the dimensions of Kalimas river.

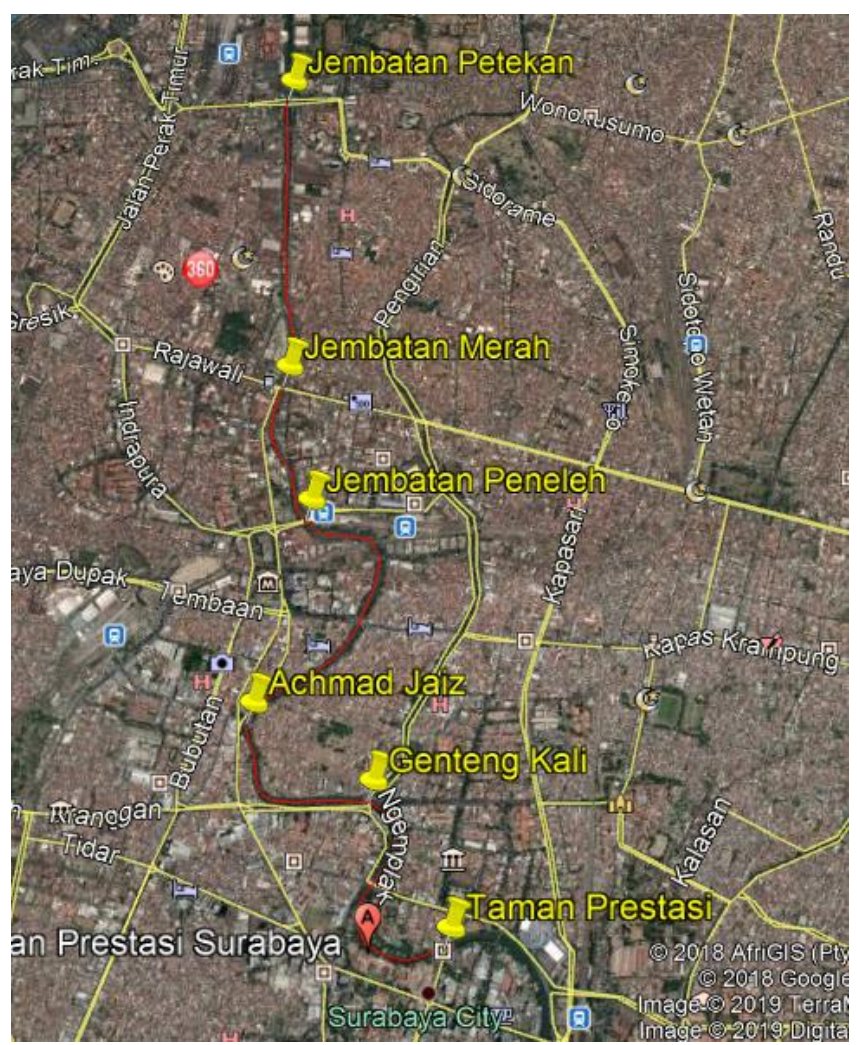

Figure 1. River Segmentation

\section{Sampling}

Determining the sampling rate based on the Indonesian National Standard (SNI) 6989.57 : 2008 where the sampling point based on river discharge. Based on secondary data, the Kalimas river water debit is $6,26 \mathrm{~m} 3 / \mathrm{second}$. So according to )SNI) 6989.57 : 2008 rivers with a flow between 5 $\mathrm{m} 3 / \mathrm{second}-150 \mathrm{~m} 3 / \mathrm{second}$, samples are taken at two points, each at $1 / 3$ and $2 / 3$ width of the river at a depth of 0,5 times the depth of survace (can be seen in Figure) then mixed. 


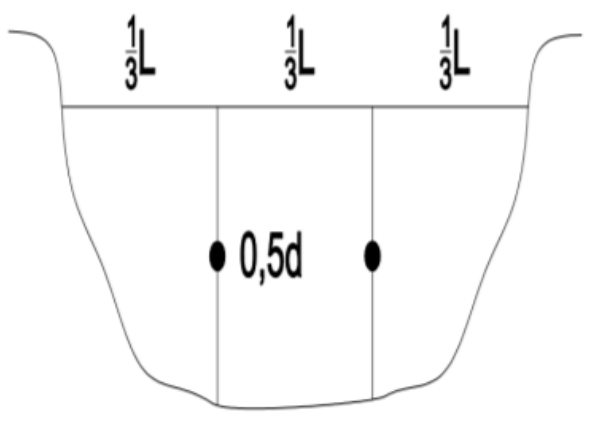

Figure 2. Sampling Point

\section{Laboratory Analysis}

Laboratory analysis is carried out to determine the quality of the river whether it has met or exceeded the quality standards set. The laboratory analysis carried out was measuring the water quality of the Kalimas River with parameters BOD, COD, TSS, DO, pH, Nitrate, Phosphate and Total Coliform.

\section{RESULTS AND DISCUSSION}

According to [6] the stages of implementing quality improvement with six sigma consist of five steps, namely using the DMAIC or Define, Measure, Analyze, Improve and Control methods. Following are the implementation of these stages in the research.

\section{A. Define}

At this stage the target of six sigma quality improvement activities is carried out. This step is to define the action plans that must be carried out to carry out improvements from each stage of the key business process.

1) Determination of Critical to Quality (CTQ)

Critical to Quality (CTQ) is a characteristic of a product or service that meets consumer needs. The Critical to Quality in this study is as follows:

1. $\mathrm{pH}$

2. DO (Dissolved Oxygen)

3. BOD (Biological Oxygen Demand)

4. COD (Chemical Oxygen Demand)

5. TSS (Total Suspended Solid)

6. Nitrat

7. Fosfat

8. Total Coliform

2) Analysis Results

Sampling is carried out at 6 points, namely point A in the upstream (Achievement Park), point 1 on the Kali Tile Road bridge, point 2 on the Peneleh bridge (Jalan Achmad Jaiz), point 3 on the JalanKebonRojo bridge, point 4 on Merat bridge and point $\mathrm{B}$ on the Petekan bridge on 2 consecutive days. Sampling is done on the steps 4 March 2019-5 March 2019 starting at 10:00. Sampling is based on Indonesian National Standard (SNI) 6989.57.2008 if the river discharge is $5-150 \mathrm{~m} / \mathrm{s}$ according to secondary data, then the sample on the river is taken at two points each at a distance of $1 / 3$ and $2 / 3$ the width of the river at depth 0.5 times the depth of the surface. The quality test results can be seen in Table 1 and Table 2.

TABLE 1.

WATER QuALiTy DATA OF KALIMAS RIVER DAY 1

\begin{tabular}{ccccccccc}
\hline \hline Titik & $\mathbf{p H}$ & $\begin{array}{c}\text { DO } \\
(\mathbf{m g} / \mathbf{l})\end{array}$ & $\begin{array}{c}\text { BOD } \\
(\mathbf{m g} / \mathbf{l})\end{array}$ & $\begin{array}{c}\text { COD } \\
(\mathbf{m g} / \mathbf{l})\end{array}$ & $\begin{array}{c}\text { TSS } \\
(\mathbf{m g} / \mathbf{l})\end{array}$ & $\begin{array}{c}\text { Nitrat } \\
(\mathbf{m g} / \mathbf{l})\end{array}$ & $\begin{array}{c}\text { Fosfat } \\
(\mathbf{m g} / \mathbf{l})\end{array}$ & $\begin{array}{c}\text { Total Koliform } \\
(\mathbf{M P N} / \mathbf{1 0 0} \mathbf{~ m l})\end{array}$ \\
\hline $\mathrm{A}$ & 7.6 & 3.3 & 6.2 & 40 & 237 & 1.186 & 0.202 & $16 \times 10^{5}$ \\
1 & 7.4 & 3 & 3.42 & 24 & 188 & 1.220 & 0.217 & $9 \times 10^{5}$ \\
2 & 7.5 & 2.9 & 4.1 & 56 & 240 & 1.127 & 0.226 & $9 \times 10^{5}$ \\
3 & 7.6 & 3.4 & 3.5 & 24 & 210 & 0.814 & 0.289 & $16 \times 10^{5}$ \\
4 & 7.4 & 2.9 & 7 & 64 & 240 & 0.859 & 0.236 & $35 \times 10^{4}$ \\
$\mathrm{~B}$ & 7.4 & 2.7 & 3.4 & 24 & 242 & 0.852 & 0.244 & $16 \times 10^{5}$ \\
\hline \hline
\end{tabular}

TABLE 2.

WATER QUALITY DATA OF KALIMAS RIVER DAY 2

\begin{tabular}{ccccccccc}
\hline \hline Titik & $\mathbf{p H}$ & $\begin{array}{c}\text { DO } \\
(\mathbf{m g} / \mathbf{l})\end{array}$ & $\begin{array}{c}\text { BOD } \\
(\mathbf{m g} / \mathbf{l})\end{array}$ & $\begin{array}{c}\text { COD } \\
(\mathbf{m g} / \mathbf{l})\end{array}$ & $\begin{array}{c}\text { TSS } \\
(\mathbf{m g} / \mathbf{l})\end{array}$ & $\begin{array}{c}\text { Nitrat } \\
(\mathbf{m g} / \mathbf{l})\end{array}$ & $\begin{array}{c}\text { Fosfat } \\
(\mathbf{m g} / \mathbf{l})\end{array}$ & $\begin{array}{c}\text { Total Koliform } \\
(\mathbf{M P N} / 100 \mathbf{m l})\end{array}$ \\
\hline $\mathrm{A}$ & 7.7 & 3.2 & 4.1 & 20.3 & 208 & 1.031 & 0.140 & $14 \times 10^{5}$ \\
1 & 7.5 & 3.1 & 6.8 & 27.6 & 180 & 1.089 & 0.148 & $3 \times 10^{6}$ \\
2 & 7.5 & 2.8 & 5.4 & 42,85 & 174 & 1.141 & 0.190 & $11 \times 10^{5}$ \\
3 & 7.5 & 2.6 & 4.7 & 20.3 & 204 & 0.773 & 0.259 & $9 \times 10^{6}$ \\
4 & 7.6 & 2.8 & 4.1 & 35.1 & 184 & 0.787 & 0.127 & $16 \times 10^{6}$ \\
B & 7.6 & 2.7 & 4.3 & 42.85 & 172 & 0.945 & 0.217 & $33 \times 10^{4}$ \\
\hline \hline
\end{tabular}

Based on Tables 1 and 2, the distribution pattern of the From Tables 1 and 2 above, it can be explained as follows: Kalimas River $\mathrm{pH}$ concentration shows a fluctuating pattern. 1. $\mathrm{pH}$ According to [7] the rising $\mathrm{pH}$ level is caused by the 
inclusion of pollutant load. Increased acidity or $\mathrm{pH}$ values are influenced by organic and inorganic istes which are discharged into the river, so the increase in $\mathrm{pH}$ at point 3 is due to the activity of domestic iste water entering the Kalimas river. According to [8] pH fluctuations are strongly influenced by the process of respiration, because of the carbon dioxide gas produced. The more carbon dioxide produced from the respiration process, the lower the $\mathrm{pH}$ will be. Class II river water quality standard for $\mathrm{pH}$ is 6-9, so that the results of the test show that the $\mathrm{pH}$ in the Kalimas River in the Taman Prestasi segment to Petekan Bridge meets Class II river water quality standards. The $\mathrm{pH}$ value can be seen in Figure 3.

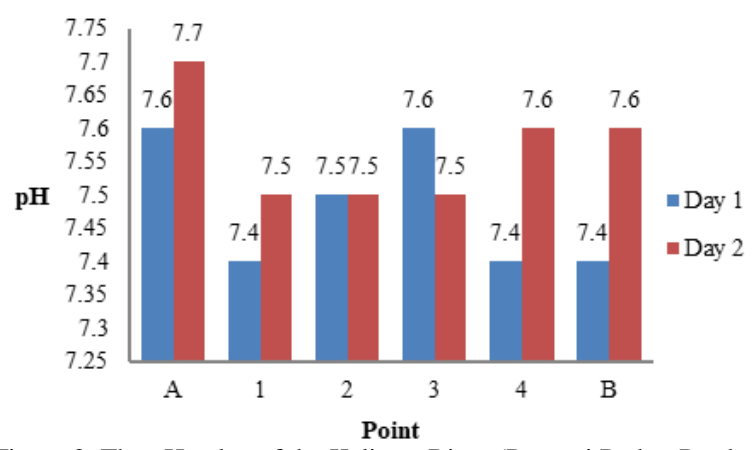

Figure 3. The $\mathrm{pH}$ value of the Kalimas River (Prestasi Park - Petekan Bridge Segment)

\section{DO (Dissolved Oxygen)}

The results of measurements of dissolved oxygen in the Kalimas river showed fluctuating results. Class II water quality standard for DO is $4 \mathrm{mg} / 1$, so the DO value at all points does not fulfill class II water quality standards. The lowest DO value is at point $\mathrm{B}$, which is on the Petekan bridge, this is caused by no opportunity for reoxygenation in the body of the water to increase oxygen levels, caused by siltation of the riverbed at the last location, and the re-entry of waste loads into the river before Petekan bridge. The DO value can be seen in Figure 4.

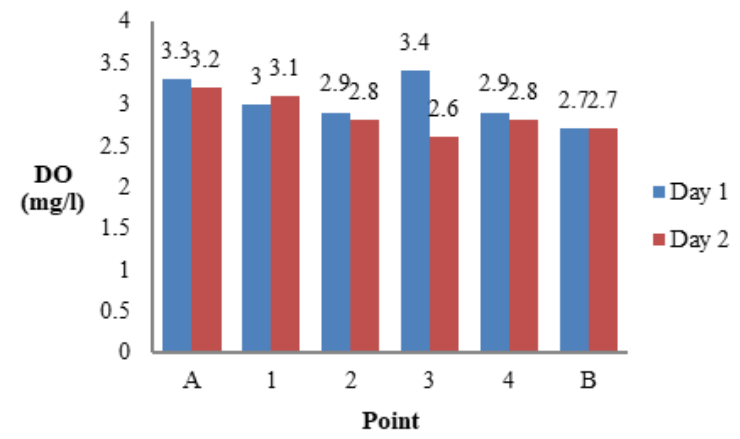

Figure 4. The DO value of the Kalimas River (Prestasi Park - Petekan Bridge Segment)

\section{BOD (Biological Oxygen Demand)}

Fluctuating distribution of BOD concentration values. Class II water quality standard value for BOD is $3 \mathrm{mg} / \mathrm{l}$, so that at all point of BOD value does not reach out the class II water quality standard. At point 2 (Penele bridge) and pount 4 (Merah bridge) BOD value has increased, an increase in
BOD value indicates that there has been an increase in the reaction of microorganisms towards organic matter from waste waterthat entering the river flow. Besides that, an increase in BOD value also indicates that in that location the incoming liquid waste has been completely mixed so that the wastewater becomes more concentrated and the decomposition activity is in high intensity. At point 1 (Genteng Kali Road bridge), point 3 (Kebon Rojo road bridge), and point $\mathrm{B}$ (Peneleh bridge) the BOD value has decreased, this decrease indicates that at that location the pollutant material has been oxidized properly and indicates an increase in oxygen level. BOD can be seen in Figure 5.

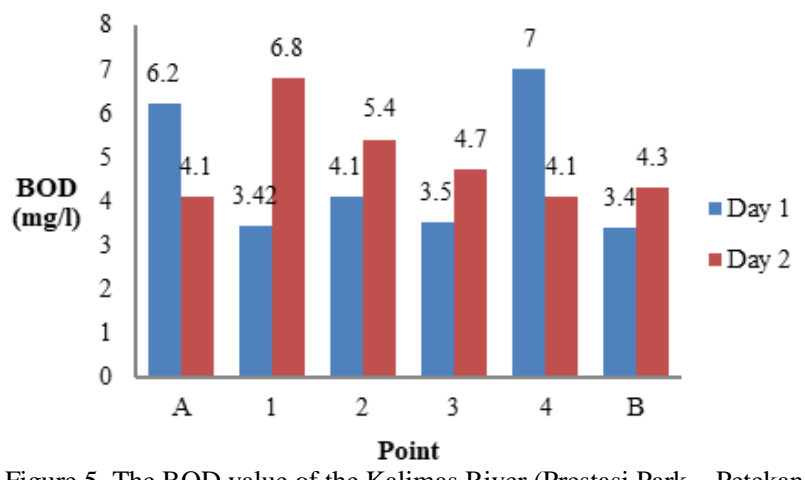

Figure 5. The BOD value of the Kalimas River (Prestasi Park - Petekan Bridge Segment)

\section{COD (Chemical Oxygen Demand)}

Based on the result of laboratory test, it shows a fluctuating distribution of COD concentration values. Class II water quality standard value for COD is $25 \mathrm{mg} / \mathrm{l}$, so that at some point the value of COD does not reach out class II water quality standards. The increase in COD value indicates that the load of waste that entering the river flow has been completely mixed and that is in line with the high value of BOD levels at that location. The COD value can be seen in Figure 6

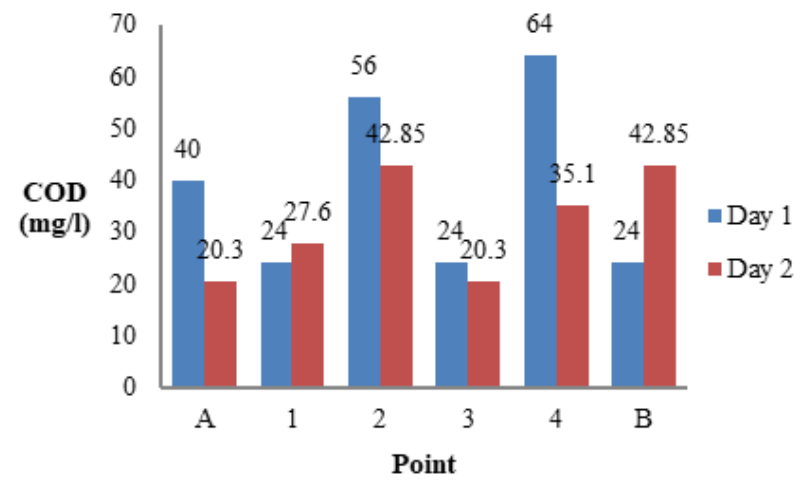

Figure 6. The COD value of the Kalimas River (Prestasi Park - Petekan Bridge Segment)

5. TSS (Total Suspended Solid)

Laboratory test result on TSS level showed a fluctuating pattern of distribution of TSS concentration. Class II water quality standard value for TSS is $50 \mathrm{mg} / 1$, so that at all TSS value points does not reach out class II water quality standards. This increase in TSS levels is probably due to the 
large amount of domestic waste water from settlement that enter the river or there is disposal of industrial wastewater. At some point there is a decrease in TSS value, this can happen because of reduced the water flow so that some TSS is sendimented and the decrease of water flow. The TSS value can be seen in Figure 7

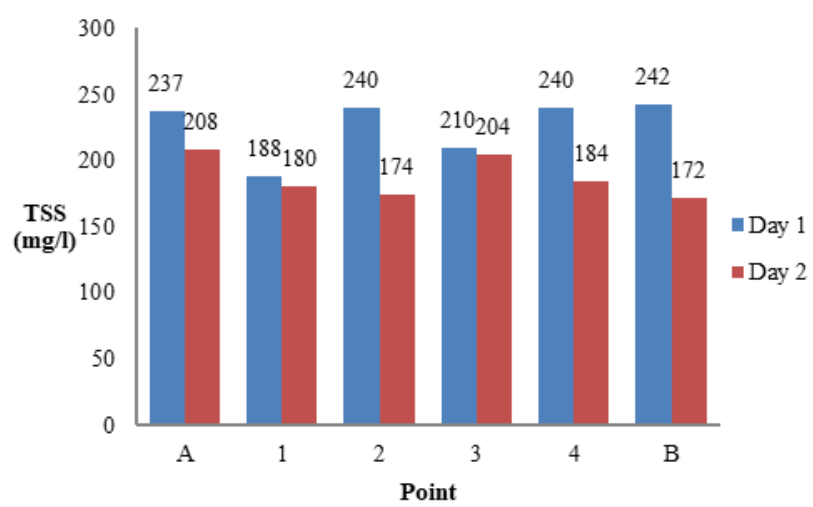

Figure 7. The TSS value of the Kalimas River (Prestasi Park - Petekan Bridge Segment)

\section{Nitrate}

Based on the result of laboratory testing, it shows a fluctuating distribution of nitrate concentration values. The class II water quality standard value for nitrate is $10 \mathrm{mg} / \mathrm{l}$, so that at all nitrate value points has reach out the class II water quality standard. The low nitrate value in the Kalimas river (Prestasi Park - Petekan Bridge Segment)is caused by the existence of the river far from the agricultural area. Nitrate value can be seen in Figure 8

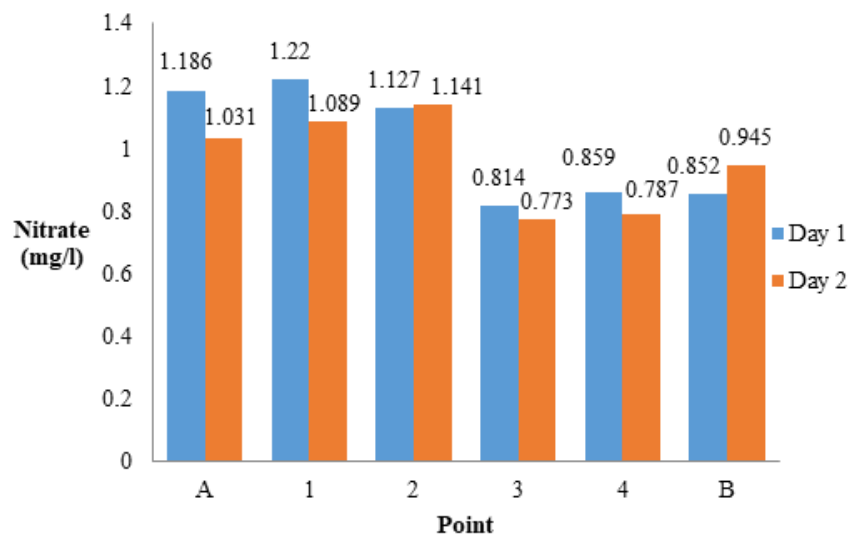

Figure 8. The nitrate value of the Kalimas River (Prestasi Park - Petekan Bridge Segment)

\section{Phosphate}

Based on the result of laboratory test, it shows a fluctuating distribution of phosphate concentration values. The class II water quality standard for phosphate is $0,2 \mathrm{mg} / \mathrm{l}$, so that at some point the phosphate value does not reach out class II water quality standard. The cause of the increase in phosphate value is due to the entry of domestic waste containing detergent. Phosphate values can be seen in Figure 9

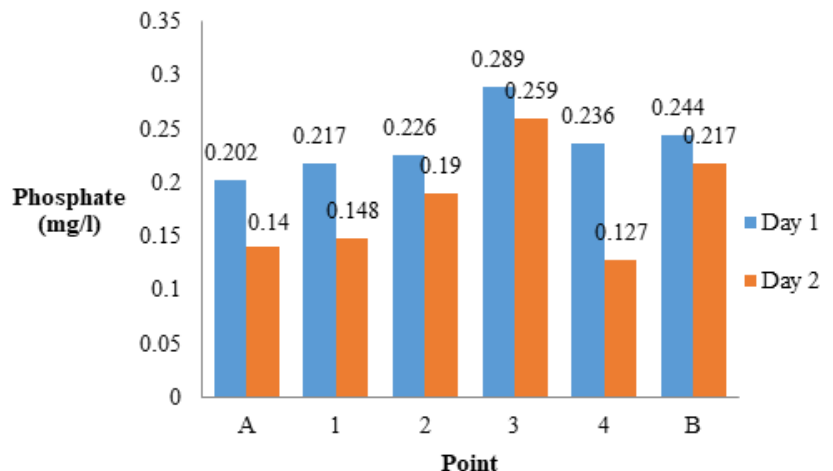

Figure 9. The phosphate value of the Kalimas River (Prestasi Park Petekan Bridge Segment)

8. Total Coliform

Based on the result of laboratory test, it shows a fluctuating distribution of the total coliform concentration. Class II water quality standard value for total coliform is 5000 MPN/100 ml, so that at all point the total coliform value does not reach out class II water quality standards. A very high total coliform value indicates that there is a direct disposal of household waste into the river also the possibility that the people around tends to expel urine and feces directly into the river. The total coliform value can be seen in Figure 10

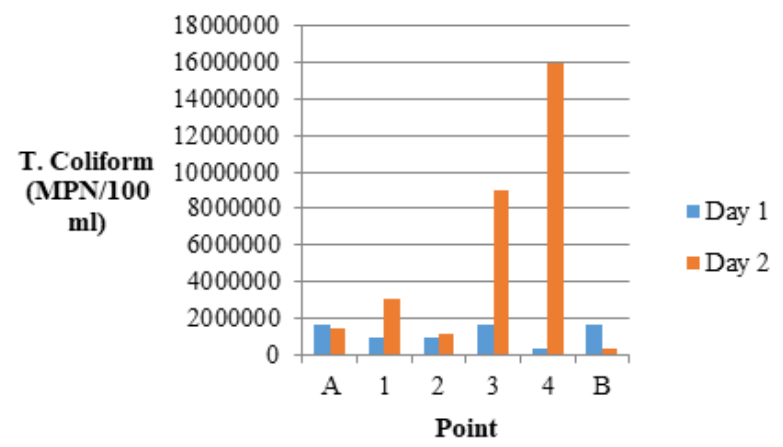

Figure 10. The total coliform value of the Kalimas River (Prestasi Park Petekan Bridge Segment)

\section{B. Measure}

In this step, collection data is used to measure performation process before reparation. The step that will be done is calculate the Deffect per Million Opportunities (DPMO) and make sure the sigma level. Calculation of the Valueof DPMO andSigma Level.

\section{1) Measuring Deffect per Unit (DPU)}

Deffects per Unit (DPU) based on the amount of average disable per unit product sample or service. DPU evaluates the average amount of unit that brings one or more disble. Commonly, DPU means the amount of average disable per product unit. There is formulation for calculating DPU

$$
\text { DPU }=\frac{\text { Total disable }}{\text { Totalsample }}
$$

\section{2) Measuring Deffect per Opportunities (DPO)}

Deffect per Opportunities (DPO) is the measurement of failure that calculated in the programe of improving six 
sigma quality, it shows how many disables or failures in each opportunity. There is formulation for calculating DPO.

$$
\mathrm{DPO}=\frac{D P U}{C T Q}
$$

3) Measuring Deffect per Million Opportunity (DPMO)

Deffect per Million Opportunity (DPMO) is the measurement of failure in the programe of improving six sigma quality, yang menunjukkan kegagalan per satu juta kesempatan. Berikut adalah rumus penentuan DPMO.

$$
\mathrm{DPMO}=\mathrm{DPO} \times 1.000 .000
$$

\section{4) Measuring Sigma Levels}

The size of sigma or sigma level is the most important variable in the six sigma method because this variable indicates the variability of the process and reaches what level the sigma process is managed. This measure also indicates whether the current process is efficient and of quality or not. After finding DPMO, sigma level values can be calculated based on a table of sigma level values. The results of DPMO calculation and sigma level can be seen in Table 3.

From the calculation of the sigma level of each parameter, the average sigma level in the Kalimas river (Prestasi Park Petekan Bridge Segment) is 2.754. To achieve class II river quality, the sigma level that must be achieved is 6 , so the Kalimas river (Petekan Bridge Achievement Park Segment) does not meet the class II river quality.
In the analysis phase, an analysis of the data that has been collected and the relationship between the data will be analyzed to find the root cause of the defect. One way to find root cause is to use Root Cause Analysis (RCA). Root Cause Analysis (RCA) is a problem-solving process to conduct an investigation into a problem of concern or incompatibility of problems found. The RCA method used in this study is Fishbone Analysis. With fishbone analysis, the root causes of problems in the Kalimas River will be found. Fishbone diagrams can be seen in Figure 11.

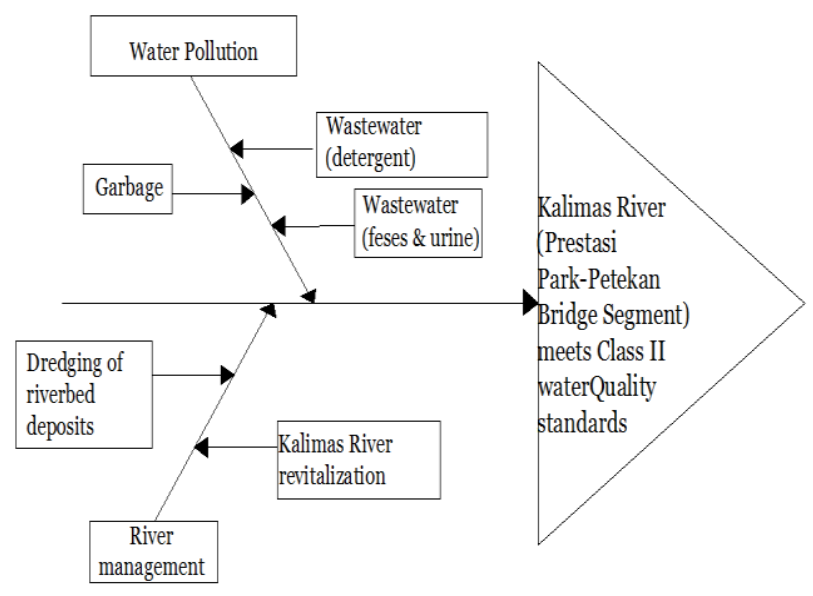

Figure 11. Fishbone Analysis

C. Analyse

TABLE 3.

\begin{tabular}{|c|c|c|c|c|c|c|c|c|}
\hline Sampel Parameter & pH & DO & BOD & COD & TSS & Nitrate & Phosphate & Total Coliform \\
\hline 1 & 7,6 & 3,3 & 6,2 & 40 & 237 & 1,186 & 0,202 & $16 \times 10^{5}$ \\
\hline 2 & 7,4 & 3,0 & 3,42 & 24 & 188 & 1,220 & 0,217 & $9 \times 10^{5}$ \\
\hline 3 & 7,5 & 2,9 & 4,1 & 56 & 240 & 1,127 & 0,226 & $9 \times 10^{5}$ \\
\hline 4 & 7,6 & 3,4 & 3,5 & 24 & 210 & 0,814 & 0,289 & $16 \times 10^{5}$ \\
\hline 5 & 7,4 & 2,9 & 7 & 64 & 240 & 0,859 & 0,236 & $35 \times 10^{4}$ \\
\hline 6 & 7,4 & 2,7 & 3.4 & 24 & 242 & 0,852 & 0,244 & $16 \times 10^{5}$ \\
\hline 7 & 7,7 & 3,2 & 4,2 & 20,3 & 208 & 1,031 & 0,140 & $14 \times 10^{5}$ \\
\hline 8 & 7,5 & 3,1 & 6,8 & 27,6 & 180 & 1,089 & 0,148 & $3 \times 10^{6}$ \\
\hline 9 & 7,5 & 2,8 & 5,4 & 42,85 & 174 & 1,141 & 0,190 & $11 \times 10^{5}$ \\
\hline 10 & 7,5 & 2,6 & 4,7 & 20,3 & 204 & 0,773 & 0,259 & $9 \times 10^{6}$ \\
\hline 11 & 7,6 & 2,8 & 4,1 & 35,1 & 184 & 0,787 & 0,127 & $16 \times 10^{6}$ \\
\hline 12 & 7,6 & 2,7 & 4,3 & 42,85 & 172 & 0,945 & 0,217 & $33 \times 10^{4}$ \\
\hline Total & - & 12 & 12 & 7 & 12 & - & 7 & 12 \\
\hline DPU & - & 1 & 1 & 0,58 & 1 & - & $\mathbf{0 , 5 8}$ & 1 \\
\hline DPO & - & 0,125 & 0,125 & $\mathbf{0 , 0 7 2 5}$ & 0,125 & - & $\mathbf{0 , 0 7 2 5}$ & 0,125 \\
\hline DPMO & - & 125 & 125 & 72.5 & 125 & - & 72.5 & 125 \\
\hline Sigma Level & - & 2,652 & 2,652 & 2,959 & 2,652 & - & 2,959 & 2,652 \\
\hline \multicolumn{9}{|c|}{ Average of sigma level 2,754} \\
\hline
\end{tabular}

DPMO AND SIGMA LEVEL 
From Figure 11 obtained from observations and problems in the field along the Kalimas river (Prestasi Park-Petekan Bridge Segment), it can be explained as follows:

1) River Management

a. Kalimas River Revitalization

In the Kalimas River Arrangement and Revitalization Plan document, it is stated that one of the strategies in revitalizing the Kalimas River is to create new green open spaces along the Kalimas River area. At present public facilities have been built along the River area, but there are still some points where there are community activities that take place along the river which can affect river conditions.

b. Dredging of riverbed deposits

The dredging program has been carried out by the government. Many residents who operate around the Kalimas river (Prestasi Park-Petekan Bridge Segment) also make more garbage entering the river, because people are accustomed to and prefer to throw garbage into the river. The content of waste originating from industrial and household waste is gradually resulting in siltation and narrowing of rivers[9].

\section{2) Water Pollution}

The causes of water pollution in the Kalimas River are:

a. Waste Water (detergent)

There are several point source and non point source sources that enter the river. Non-point source sources that come from residential waste, offices, hotels, etc. contain a lot of detergent because in addition to detergent waste water from households, laundry business waste is also included in non-point source pollutant sources that enter the river. The use of detergent which is not accompanied by a good degradation process will cause siltation of the waters or the emergence of eutrophication (enrichment of nutrients), so that oxygen transfer is hampered and results in disruption decomposition process of waste in the waters. The detergent content also results in an increase in phosphate contained in water bodies

b. Waste Water (feses and urine)

The source of non-point source pollutants that enter the Kalimas river (Prestasi Park-Petekan Bridge Segment) is in the form of domestic waste. Apart from non-point source, faecal and urine waste that enters the river is also caused by the presence of several people who directly dispose of their waste into the river. Human waste can produce pathogenic

TABLE 4

IMPROVE STAGE

\begin{tabular}{cll}
\hline \hline \multicolumn{1}{c|}{ Problem } & \multicolumn{1}{c}{ Solution } & \multicolumn{1}{c}{ Information } \\
\hline & Control of illegal buildings around the river & $\begin{array}{l}\text { All forms of buildings and activities that are not the result of revitalization } \\
\text { must be moved. Because community activities that are not organized around } \\
\text { the river can affect river water quality due to the tendency of masrayakat to } \\
\text { directly dispose of waste and garbage into the river }\end{array}$ \\
\cline { 2 - 3 } River management & $\begin{array}{l}\text { Before the dredging schedule is set, the characteristics of the river must be } \\
\text { identified, which include discharge, tidal river water and sediment analysis. } \\
\text { Then the dredging simulation analysis is carried out, where the dredging } \\
\text { tool also affects. After a new simulation can be determined the effectiveness } \\
\text { of dredging and also the dredging schedule }\end{array}$ \\
\hline
\end{tabular}

bacteria in the form of Escherichia coli, Shigella sp., Vibrio cholera, Campylobacter jejun and fecal coliform. These bacteria can cause diarrhea in humans.Escherechia coli if consumed in the long term will have an impact on the emergence of diseases such as inflammation of the intestine, diarrhea, infections of the urinary tract and bile duct[10]. According to [11] the effect of faeces or other food scraps still dominates as a factor causing pollution of the water environment. Stool is included in organic waste, where organic waste causes BOD and COD values in water river become tall. BOD is a picture of easily decomposed organic material in the waters while COD is the amount of oxygen needed to break down all organic matter contained in water. c. Garbage

There is still a lot of garbage in the Kalimas river (Prestasi Park-Petekan Bridge Segment). Most of the garbage in the river is plastic waste and also dried leaves. In addition, food waste such as watermelon, Styrofoam waste, baby diaper waste and so on are also found. According to [11] waste that is directly discharged into the river causes a high number of coliforms in the river. Organic waste that enters the river also causes the BOD and COD values in the river to be high. While onorganic waste that floats in the river, for example, plastic can block the sunlight entering the river, which interferes with the photosynthesis process in the river.

\section{Improve}

In this step an action plan is implemented to carry out the improvement of six sigma quality. After knowing the root of the problem from the analysis stage, recommendations are proposed for general corrective actions in an effort to reduce the level of disability. The improve phase improves the process target by designing creative solutions to overcome and prevent problems. Solutions proposed can be seen in Table 4

\section{E. Control}

The last stage of the six sigma method is the control stage. At this stage the control will be determined when the solution given at the improve stage is carried out. The function at this stage of control is so that the solutions implemented can run well and check whether the solutions applied provide effective results. The control stage can be seen in Table 5 . 


\begin{tabular}{lll}
\hline $\begin{array}{l}\text { Engaging the community in managing the } \\
\text { river environment }\end{array}$ & $\begin{array}{l}\text { The community must play an active role in river management because the } \\
\text { surrounding community is indirectly related to all activities around the river }\end{array}$ \\
\hline $\begin{array}{l}\text { Public awareness about household waste } \\
\text { management and not throwing household } \\
\text { waste into the body of the Kalimas River }\end{array}$ & $\begin{array}{l}\text { Counseling or socialization from the government or related institutions is } \\
\text { important to increase public awareness. In addition, the government can also } \\
\text { hold activities related to rivers to increase public awareness. }\end{array}$ \\
\hline $\begin{array}{l}\text { Law enforcement to industries or other actors } \\
\text { proven to pollute the river by means of active } \\
\text { cooperation in monitoring and monitoring the } \\
\text { industry by involving the community. }\end{array}$ & $\begin{array}{l}\text { Existing laws must be strictly enforced. In addition to the government, the } \\
\text { community must also play an active role if they know there are actors who } \\
\text { pollute the river. }\end{array}$ \\
\hline $\begin{array}{l}\text { Map potential pollutant sources } \\
\text { River Pollution }\end{array}$ & $\begin{array}{l}\text { Mapping pollutant sources can be useful in the future for periodic } \\
\text { monitoring of the source of the Kalimas river pollution. }\end{array}$ \\
\cline { 2 - 3 } $\begin{array}{l}\text { Implementation of online monitoring of river } \\
\text { water quality that has been developed by }\end{array}$ & $\begin{array}{l}\text { Online monitoring has been implemented in several rivers in Indonesia. To } \\
\text { facilitate quality monitoring, online monitoring can also be applied in the } \\
\text { KaPT }\end{array}$ & $\begin{array}{l}\text { Allimas river development that requires an AMDAL, RKL, RPL must make an } \\
\text { AMDAL, RKL, RPL and fulfill all that is stated in it, so that the quality of } \\
\text { the Kalimas river is maintained even though there is a burden of pollutants } \\
\text { entering the river. }\end{array}$ \\
\hline
\end{tabular}

\begin{tabular}{|c|c|c|}
\hline \multicolumn{3}{|r|}{$\begin{array}{l}\text { TABLE } 5 . \\
\text { CONTROL STAGE }\end{array}$} \\
\hline No & Solution & Control \\
\hline 1 & Control of illegal buildings around the river & $\begin{array}{l}\text { Check directly into the field so that residents do not return to carry out activities } \\
\text { around the river, as well as control if there are people who violate. }\end{array}$ \\
\hline 2 & Periodic dredging & $\begin{array}{l}\text { Before the dredging schedule is set, the characteristics of the river must be } \\
\text { identified, which include discharge, tidal river water and sediment analysis. Then } \\
\text { the dredging simulation analysis is carried out, where the dredging tool also affects. } \\
\text { After a new simulation can be determined the effectiveness of dredging and also the } \\
\text { dredging schedule. }\end{array}$ \\
\hline 3 & $\begin{array}{l}\text { Engaging The Community In Managing The River } \\
\text { Environment }\end{array}$ & $\begin{array}{l}\text { It needs to be documented and also disseminated to the community about what } \\
\text { activities have been carried out and also the positive impacts that have occurred on }\end{array}$ \\
\hline 4 & $\begin{array}{l}\text { Public awareness about household waste } \\
\text { management and not throwing household waste into } \\
\text { the body of the Kalimas River }\end{array}$ & the Kalimas river (segment of the Bridge Achievement Bridge) \\
\hline 5 & $\begin{array}{l}\text { Law enforcement to industries or other actors proven } \\
\text { to pollute the river by means of active cooperation in } \\
\text { monitoring and monitoring the industry by involving } \\
\text { the community. }\end{array}$ & $\begin{array}{l}\text { Periodically check industries that dispose of waste into the Kalimas river (segment } \\
\text { of the Bucket Bridge Park) }\end{array}$ \\
\hline 6 & Map potential pollutant sources & $\begin{array}{l}\text { Periodically check the Kalimas river (Petekan Bridge-Achievement Park segment) } \\
\text { related to whether there are new sources of pollutants entering the river }\end{array}$ \\
\hline 7 & $\begin{array}{l}\text { Implementation of online monitoring of river water } \\
\text { quality that has been developed by BPPT }\end{array}$ & Periodically check and maintain the tools used. \\
\hline 8 & Enforcement of AMDAL, RKL, RPL & $\begin{array}{l}\text { Checking every development around the river, especially development, which must } \\
\text { be equipped with AMDAL, RKL, RPL }\end{array}$ \\
\hline
\end{tabular}

\section{CONCLUSION}

The conclusions from the research and analysis that have been done are:

1. The main cause of the quality of the Kalimas river (Prestasi Park-Petekan Bridge Segment)does not meet the class II river water quality standards based on Root Cause Analysis (RCA) is river management and river pollution.
2. With the Six Sigma Method it was found that the quality of the Kalimas river (Prestasi Park-Petekan Bridge Segment) did not meet the class II river water quality standards. The sigma level value for the Kalimas river (Petekan Bridge Achievement Park Segment) is 2.754, while to meet the class II river water quality standard the value of the sigma level that must be achieved is 6 . 
The $1^{\text {st }}$ International Conference on Business and Management of Technology (IConBMT)

August 3rd 2019, Institut Teknologi Sepuluh Nopember, Surabaya, Indonesia

\section{REFERENCES}

[1] M. Dawud, I. Namara, N. Chayati, and F. Muhammad, "Analisis sistem pengendalian pencemaran air Sungai Cisadane Kota Tangerang berbasis masyarakat," in Prosiding SEMNASTEK 2016, 2016, vol. 0, no. 0, pp. 1-8.

[2] L. Maghfiroh, "Penentuan Daya Tampung Beban Pencemaran Sungai Kalimas Surabaya (Segmen Taman Prestasi-Jembatan Petekan) Dengan Pemodelan QUAL2Kw," Institut Teknologi Sepuluh Nopember, 2016.

[3] D. Rimantho and D. M. Mariani, "Penerapan metode six sigma pada pengendalian kualitas air baku pada produksi makanan," $J$. Ilm. Tek. Ind., vol. 16, no. 1, pp. 1-12, Jul. 2017.

[4] D. Didiharyono, M. Marsal, and B. Bakhtiar, "Analisis pengendalian kualitas produksi dengan metode six sigma pada industri air minum PT Asera Tirta Posidonia, Kota Palopo," SAINSMAT J. Ilm. Ilmu Pengetah. Alam, vol. 7, no. 2, pp. 163 176, Sep. 2018.

[5] M. Ertürk, M. Tuerdi, and A. Wujiabudula, "The effects of six sigma approach on business performance: A study of white goods (home appliances) sector in Turkey," Procedia - Soc. Behav. Sci., vol. 229, pp. 444-452, Aug. 2016.
[6] K. Afni, M. Muantulloh, E. Krisnaningsih, and E. Kristiningrum, "Analisis mutu air dengan pendekatan six sigma untuk peningkatan mutu plat baja," J. Stand., vol. 19, no. 2, p. 155, Mar. 2018.

[7] E. Ramadhani, "Analisis Pencemaran Kualitas Air Sungai Bengawan Solo Akibat Limbah Industri di Kecamatan Kebakkramat Kabupaten Karanganyar," Universitas Muhammadiyah Surakarta, 2016.

[8] D. Suhmana, "Dinamika Kualitas Air Pada Berbagai Penggunaan Lahan Di Sub DAS Cisadane," Institut Pertanian Bogor, 2012.

[9] S. Susmarkanto, "Pencemaran lingkungan perairan sungai salah satu faktor penyebab banjir Kota Jakarta," J. Teknol. Lingkung., vol. 3, no. 1, pp. 13-16, Aug. 2011.

[10] D. A. Santy, S. Adyatma, and N. Huda, "Analisis kandungan bakteri fecal coliform pada Sungai Kuin Kota Banjarmasin," Maj. Geogr. Indones., vol. 31, no. 2, p. 51, Dec. 2017.

[11] S. Khotimah, "Kepadatan bakteri Coliform di Sungai Kapuas Kota Pontianak," Pros. SEMIRATA 2013, vol. 1, no. 1, pp. 339349, Sep. 2013. 